\title{
PIK3C2B wt Allele
}

National Cancer Institute

\section{Source}

National Cancer Institute. PIK3C2B wt Allele. NCI Thesaurus. Code C102943.

Human PIK3C2B wild-type allele is located in the vicinity of $1 \mathrm{q} 32$ and is approximately 72 $\mathrm{kb}$ in length. This allele, which encodes phosphatidylinositol 4-phosphate 3-kinase C2 domain-containing subunit beta protein, plays a role in the regulation of phosphoinositol signaling. 